Article

\title{
Optimal Replacement of Soybean Meal with Fermented Palm Kernel Meal as Protein Source in a Fish Meal-Soybean Meal-Based Diet of Sex Reversed Red Tilapia (Oreochromis niloticus $\times$ O. mossambicus)
}

\author{
Wattana Wattanakul ${ }^{1, *(D)}$, Karun Thongprajukaew ${ }^{2}(D)$, Waraporn Hahor ${ }^{2}$ and Naraid Suanyuk ${ }^{3}$ \\ 1 Department of Aquaculture and Fisheries Products, Faculty of Science and Fisheries Technology, \\ Rajamangala University of Technology Srivijaya, Trang 92150, Thailand \\ 2 Division of Health and Applied Sciences, Faculty of Science, Prince of Songkla University, \\ Songkhla 90112, Thailand; karun.t@psu.ac.th (K.T.); tarn.something@gmail.com (W.H.) \\ 3 Kidchakan Supamattaya Aquatic Animal Health Research Center, Aquatic Science and Innovative \\ Management Division, Faculty of Natural Resources, Prince of Songkla University, Songkhla 90112, Thailand; \\ naraid.s@psu.ac.th \\ * Correspondence: wattanakul67@gmail.com; Tel.: +66-7520-4053
}

Citation: Wattanakul, W.;

Thongprajukaew, K.; Hahor, W.; Suanyuk, N. Optimal Replacement of Soybean Meal with Fermented Palm Kernel Meal as Protein Source in a Fish Meal-Soybean Meal-Based Diet of Sex Reversed Red Tilapia

(Oreochromis niloticus $\times O$.

mossambicus). Animals 2021, 11, 2287. https://doi.org/10.3390/ani11082287

Received: 29 June 2021

Accepted: 30 July 2021

Published: 3 August 2021

Publisher's Note: MDPI stays neutral with regard to jurisdictional claims in published maps and institutional affiliations.

Copyright: (c) 2021 by the authors. Licensee MDPI, Basel, Switzerland. This article is an open access article distributed under the terms and conditions of the Creative Commons Attribution (CC BY) license (https:// creativecommons.org/licenses/by/ $4.0 /)$.
Simple Summary: Replacement effects of soybean meal (SBM) with fermented palm kernel meal (FPKM) as a protein source was investigated in sex-reversed red tilapia. The two-month-old fish were fed fish meal-SBM-based diets with replacement by FPKM at 25\% (25FPKM), 50\% (50FPKM), 75\% (75FPKM) and 100\% (100FPKM) for 12 weeks, while an FPKM-free diet (0FPKM) was used as a control. Based on growth performance, feed utilization, digestive enzyme activities, flesh quality, carcass composition, hematological parameters and liver histoarchitecture, the $50 \%$ replacement level of SBM by FPKM support this alternative. Findings from the current study support the use of FPKM in aquafeed production, providing a low-cost diet for tilapia farming.

Abstract: The solid-state fermentation by effective microorganisms (containing photosynthetic bacteria, lactic acid bacteria, nitrogen-fixing bacteria, yeast and Bacillus sp.) improved the nutritive values of palm kernel meal (PKM). Increased crude protein (20.79\%), nitrogen-free extract (40.07\%) and gross energy $(19.58 \%)$ were observed in fermented PKM (FPKM) relative to raw PKM while crude lipid (15.65\%), crude fiber (36.45\%) and ash (29.54\%) were decreased. Replacement of soybean meal (SBM) with FPKM as a protein source was investigated for its effects in sex-reversed red tilapia (Oreochromis niloticus $\times$ O. mossambicus). The two-month-old fish (14.85 $\pm 0.28 \mathrm{~g}$ initial weight) were fed fish meal-SBM-based diets with replacement by FPKM at 25\% (25FPKM), 50\% (50FPKM), 75\% (75FPKM) and 100\% (100FPKM), while an FPKM-free diet (OFPKM) was used as a control. The five treatments, comprising triplicate cement ponds and forty fish each, were conducted in a recirculating system over 12 weeks. At the end of the feeding trial, fish fed the 50FPKM diet were superior in growth performance, while the feed utilization parameters were similar across all five treatments. Physiological adaptation of the protein-digesting (pepsin and trypsin) and lipid-digesting (lipase) enzymes was detected at all protein replacement levels (except for 25FPKM), as well as of the enzyme for cellulose digestion (cellulase), but not of the carbohydrate-digesting enzymes (amylase). Protein synthesis capacity in flesh was improved in fish fed the 50FPKM diet, while the quality of the main flesh proteins, actin and myosin, showed no significant differences across the five treatments. No differences in carcass composition and no negative effects on hematological parameters or liver histoarchitecture at the 50\% replacement level of SBM by FPKM also support this alternative. Findings from the current study indicate the low-cost FPKM-containing diet for tilapia in comparison with control diet.

Keywords: carcass; digestive enzyme; feed utilization; flesh quality; hematological parameter; liver 


\section{Introduction}

Nile tilapia (Oreochromis niloticus) is an economically important fish species that is widely cultured around the world [1]. These fish are a good alternative protein source for human consumption, especially in tropical and subtropical zones [2]. Red tilapia (O. niloticus $\times$ O. mossambicus) is popular due to its attractive color and good taste, increasing its marketability [3]. Similar to other economic fish species, the cost of main protein ingredients (mainly fish meal) for formulating the pellet diets is continuously increasing [4]. Therefore, the protein sources from plant by-products have been used to replace fish meal in fish diets $[5,6]$, as have low-cost animal by-products $[7,8]$.

Soybean meal (SBM) is the main plant protein in practical fish feed production. This feedstuff is moderately rich in protein, produced in great quantities, reasonably priced, and has relatively well-balanced amino acid profile among the plant by-product meals $[9,10]$. The presence of anti-nutritional compounds (including goitrin, phytohemagglutinins, lectins, non-starch polysaccharides, phytate, phytoestrogens, protein antigens, saponins and trypsin inhibitor) are disadvantages of this plant by-product in aquafeed production $[11,12]$. Therefore, the replacement of SBM by low-cost plant protein sources is worth considering in the aquaculture sector.

Palm kernel meal (PKM) is mainly produced in South-East Asian and African countries. This by-product is obtained from palm kernel oil extraction processes and is generally used in feeds for terrestrial animals $[13,14]$ and as a component in fish feed formulations [15-18]. Poor usability in aquafeed is due to the large amount of cell wall constituents, low protein content and amino acid deficiencies $[15,16]$. Biological pretreatment of the PKM for improving its nutritive value appears to have potential, via enzyme supplementation and fermentation by cellulolytic or cocktail enzymes [14-16].

Effective microorganisms (EMs) are various blends of common predominantly anaerobic microorganisms, probably including lactic acid bacteria (LAB), photosynthetic bacteria, yeast and naturally beneficial microorganisms. Worldwide, EMs support sustainable practices in farming, composting and mitigation of environmental pollution. In animal nutrition research, EMs have been applied to benefit economic terrestrial and aquatic animals [19]. Various enzymes produced by the EMs might improve the nutritive value of PKM. Therefore, replacement effects of SBM protein by fermented PKM (FPKM) were investigated in sex-reversed red tilapia in the current study. The commercially available EM (EM-Plus, Microbe for Life, Bangkok, Thailand) that contains photosynthetic bacteria, $\mathrm{LAB}$, nitrogen-fixing bacteria, yeast and Bacillus sp. was used in the current study since it is widely used by Thai farmers. The suitable replacement levels were assessed from growth performance, feed utilization, digestive enzyme specific activities, flesh quality, carcass composition, hematological parameters and liver histoarchitecture.

\section{Materials and Methods}

\subsection{Preparation of FPKM}

The PKM was obtained from Phatthalung Livestock CO., LTD, Phatthalung, Thailand. This by-product was fermented with activated effective microorganisms (EM-Plus, Microbe for Life, Bangkok, Thailand) that contain photosynthetic bacteria, LAB, nitrogen-fixing bacteria, yeast and Bacillus sp. The solid-state fermentation was performed by mixing PKM with liquid EM $(5 \% v / w)$, molasses $(5 \% v / w)$ and then adding water $(5 \% v / w)$. These mixtures were packed in polyethylene bags, sealed and incubated for 30 days in dark at ambient temperatures $\left(30-31^{\circ} \mathrm{C}\right)$.

\subsection{Preparation of the Experimental Diets}

The formulations and ingredients of the experimental diets are shown in Table 1. All the experimental diets were formulated to contain approximately $30 \%$ crude protein and 10\% crude lipid on averages. The protein from SBM was replaced by FPKM at 25\% (25FPKM), 50\% (50FPKM), 75\% (75FPKM) and 100\% (100FPKM), while an FPKM-free diet (OFPKM) was used as the control. Fish meal and SBM were used as main protein 
sources, while carbohydrate sources included corn meal, broken rice and rice bran. All dry ingredients were finely ground to 80 mesh particle size, weighed accurately and then mixed for $10 \mathrm{~min}$ in a mixer. Pre-weighed lipid sources (fish oil and soybean oil) were slowly blended, followed by vitamin-mineral premixes and $30 \%$ by weight of distilled water. The glutinous mixture was passed through a meat mincer $(4-6 \mathrm{~mm})$, dried at $60^{\circ} \mathrm{C}$ for $24 \mathrm{~h}$, sifted to remove any fine particles and then kept in polyethylene bags at $4{ }^{\circ} \mathrm{C}$ until feeding.

Table 1. Formulations and proximate compositions of experimental diets containing varying levels of FPKM.

\begin{tabular}{|c|c|c|c|c|c|}
\hline Item & 0FPКМ & 25FРКМ & 50FРКМ & 75FPKM & 100FPKM \\
\hline \multicolumn{6}{|l|}{ Ingredient } \\
\hline Fish meal & 26.9 & 30.8 & 34.8 & 38.8 & 42.7 \\
\hline SBM & 25.0 & 18.8 & 12.5 & 6.2 & - \\
\hline FPKM & - & 6.2 & 12.5 & 18.8 & 25.0 \\
\hline Corn meal & 15.9 & 14.2 & 12.5 & 10.8 & 9.1 \\
\hline Broken rice & 12.7 & 11.4 & 10.0 & 8.6 & 7.3 \\
\hline Rice bran & 8.5 & 7.6 & 6.7 & 5.8 & 4.9 \\
\hline Fish oil & 2 & 2 & 2 & 2 & 2 \\
\hline Soybean oil & 2 & 2 & 2 & 2 & 2 \\
\hline Alfa starch & 4 & 4 & 4 & 4 & 4 \\
\hline Vitamin-mineral premix ${ }^{a}$ & 3 & 3 & 3 & 3 & 3 \\
\hline \multicolumn{6}{|c|}{ Proximate composition ( $\%$ fed basis) } \\
\hline Moisture & 5.84 & 5.96 & 5.81 & 5.90 & 5.91 \\
\hline Crude protein & 30.63 & 29.87 & 30.61 & 30.22 & 30.05 \\
\hline Crude lipid & 10.13 & 10.90 & 10.11 & 9.54 & 9.50 \\
\hline Crude ash & 13.28 & 14.50 & 15.37 & 17.22 & 18.78 \\
\hline Crude fiber & 7.28 & 7.47 & 7.82 & 8.03 & 8.98 \\
\hline NFE & 32.84 & 31.30 & 30.28 & 29.09 & 26.78 \\
\hline $\mathrm{GE}\left(\mathrm{kJ} \mathrm{g}^{-1}\right)$ & 16.88 & 16.74 & 16.43 & 15.90 & 14.45 \\
\hline
\end{tabular}

SBM, soybean meal; FPKM, fermented palm kernel meal; NFE, nitrogen-free extract; GE, gross energy. ${ }^{a}$ Vitamin-mineral premix, $1 \mathrm{~kg}$ contained $1000 \mathrm{U}$ vitamin $\mathrm{A}, 250 \mathrm{U}$ vitamin $\mathrm{D}_{3}, 5 \mathrm{U}$ vitamin $\mathrm{E}, 2000 \mathrm{mg}$ vitamin $\mathrm{B}_{1}, 800 \mathrm{mg}$ vitamin $\mathrm{B}_{2}, 2000 \mathrm{mg}$ vitamin $\mathrm{B}_{6}, 1 \mathrm{mg}$ vitamin $\mathrm{B}_{12}, 10,000 \mathrm{mg}$ vitamin C, $300 \mathrm{mg}$ pantothenic acid, $5000 \mathrm{mg}$ nicotinic acid, $200 \mathrm{mg}$ folic acid, $2 \mathrm{mg}$ biotin, $500 \mathrm{mg}$ iron, $7000 \mathrm{mg}$ zinc, $2 \mathrm{mg}$ biotin, $800 \mathrm{mg}$ manganese, $10 \mathrm{mg}$ selenium, 15,000 mg lysine, $3000 \mathrm{mg}$ methionine.

\subsection{Proximate Compositions of Ingredients and Experimental Diets}

Proximate chemical compositions of ingredients (PKM and FPKM) and experimental diets were analyzed for moisture, crude protein, crude lipid, crude fiber and ash, according to standard methods of AOAC [20]. Nitrogen-free extract (NFE) and gross energy (GE, $\mathrm{kJ} \mathrm{g}^{-1}$ ) were calculated as [100 - (moisture + crude protein + crude lipid + crude fiber + ash $)]$ and as [(crude protein $\times 23.6)+(\mathrm{NFE} \times 17.2)+($ crude lipid $\times 39.5)]$, respectively. All the chemical analyses were performed in duplicates and are expressed as $\%$ dry matter.

\subsection{Fish Feeding Trial}

Transportation, husbandry, feeding trial and sampling of animals in the current study conformed to the "Ethical Principles and Guidelines for the Use of Animals for Scientific Purposes", National Research Council, Thailand (Application No. UI-027712559 and U1-06514-2560). Two-month-old sex-reversed red tilapia were purchased from Phatthalung Inland Fisheries Research and Development Center, Phatthalung, Thailand. The fish were acclimatized for 10 days in a $4000 \mathrm{~L}$ cement pond $(1 \mathrm{~m} \times 4 \mathrm{~m} \times 1 \mathrm{~m})$ and fed with OFPKM diet twice daily $(08.00$ and $16.00 \mathrm{~h})$ to satiation. Subsequently, forty fish each (14.85 $\pm 0.28 \mathrm{~g}$ initial weight) were randomly distributed into cement ponds $(1 \mathrm{~m} \times 2 \mathrm{~m} \times 0.6 \mathrm{~m})$ with $40 \mathrm{~cm}$ water depth. There were fifteen experimental units in total-five treatments with three replicates each. The fish were fed with $10 \%$ of body weight (BW) per day and the feed amount was adjusted weekly according to the actual feeding performance. Experimentation was conducted under a $12 \mathrm{~h}$ light $/ 12 \mathrm{~h}$ dark natural light cycle. Recirculating aquaculture system was used, controlling the water quality 
to $\mathrm{pH} 7.91 \pm 0.06,28.73 \pm 0.22{ }^{\circ} \mathrm{C}$ temperature, $6.11 \pm 0.11 \mathrm{mg} \mathrm{L}^{-1}$ dissolved oxygen, $97.80 \pm 1.47 \mathrm{mg} \mathrm{L}^{-1}$ alkalinity, $0.54 \pm 0.04 \mathrm{mg} \mathrm{L}^{-1}$ ammonia and $0.61 \pm 0.03 \mathrm{mg} \mathrm{L}^{-1}$ nitrite. Uneaten feed was collected $1 \mathrm{~h}$ after feeding, dried at $60^{\circ} \mathrm{C}$ until constant weight and used to calculate the feeding rate (FR), the feed conversion ratio (FCR) and the protein efficiency ratio (PER). At the end of 12 weeks of trial, all the fish were starved for $24 \mathrm{~h}$, anesthetized by quinaldine and then body weight and length were measured for every fish. Nine fish from each dietary treatment were harvested, minced and then stored at $-20{ }^{\circ} \mathrm{C}$ until use for whole carcass proximate composition analysis. Nine samples from the remaining fish were used for collecting blood, stomach, intestine, liver and white muscle. Blood samples were collected from the caudal vessel after anesthetization. The samples were kept at $4{ }^{\circ} \mathrm{C}$ and all hematological parameters were determined within $12 \mathrm{~h}$ after collection. The fish were dissected by sterilized scalpels on ice and then stomach and intestinal samples were carefully removed and stored at $-20^{\circ} \mathrm{C}$ until use for digestive enzyme assay. Liver samples were immediately removed and then fixed in $10 \%$ neutral-buffered formalin. The skin and scales were removed before collecting white muscle (epaxial muscle below the dorsal fin) for flesh quality assessment. Growth performance and feed utilization parameters were calculated as follows:

Survival $(\%)=100 \times[$ Final fish number $/$ initial fish number $]$

Fulton's condition factor $(K)=100 \times\left[\right.$ Live body weight $(\mathrm{g}) /$ total body length $\left.(\mathrm{cm})^{3}\right]$

Daily growth coefficient $\left(\mathrm{DGC}, \% \mathrm{BW}\right.$ day $\left.^{-1}\right)=100 \times\left[\left(\mathrm{W}_{\mathrm{t}}\right)^{1 / 3}-\left(\mathrm{W}_{0}\right)^{1 / 3} /\left(\mathrm{t}-\mathrm{t}_{0}\right)\right]$

where $\mathrm{W}_{\mathrm{t}}=$ mean weight $(\mathrm{g})$ at day $\mathrm{t}, \mathrm{W}_{0}=$ mean weight $(\mathrm{g})$ at day $\mathrm{t}_{0}$.

Feeding rate $\left(\mathrm{FR}, \% \mathrm{BW}\right.$ day $\left.^{-1}\right)=\mathrm{C} /\left[\left(\mathrm{W}_{0}+\mathrm{W}_{\mathrm{t}}\right) / 2\right] / \mathrm{t} \times 100$

where $\mathrm{C}$ = daily feed consumption $(\mathrm{g}), \mathrm{W}_{0}=$ initial body weight $(\mathrm{g}), \mathrm{W}_{\mathrm{t}}=$ final body weight $(\mathrm{g}), \mathrm{t}=$ feeding duration (day).

Feed conversion ratio $\left(\mathrm{FCR}, \mathrm{g}\right.$ feed $\mathrm{g}$ gain $\left.{ }^{-1}\right)=$ Dry feed consumed $(\mathrm{g}) /$ wet weight gain $(\mathrm{g})$

Protein efficiency ratio (PER, g gain g protein ${ }^{-1}$ ) $=$ Wet weight gain $(\mathrm{g}) /$ protein intake $(\mathrm{g})$

\subsection{Digestive Enzyme Studies}

Crude extract from the frozen digestive organs (stomach or intestine) were prepared by homogenizing the target tissues in $0.2 \mathrm{M} \mathrm{Na}_{2} \mathrm{HPO}_{4}-\mathrm{NaH}_{2} \mathrm{PO}_{4}$ buffer at $\mathrm{pH} 8(1: 3 \mathrm{w} / \mathrm{v})$ using a micro-homogenizer (THP-220; Omni International, Kennesaw, GA, USA). The homogenate was centrifuged at $15,000 \times g$ for $30 \mathrm{~min}$ at $4{ }^{\circ} \mathrm{C}$, and then the supernatant was collected and kept at $-20^{\circ} \mathrm{C}$ until use. The protein concentration in crude enzyme extract was assayed using the method of Lowry et al. [21] within the linear range for standard bovine serum albumin (BSA). The concentration of the soluble protein $\left(\mathrm{mg} \mathrm{mL}^{-1}\right)$ was used to quantify the enzyme specific activities $\left(\mathrm{U} \mathrm{mg}\right.$ protein ${ }^{-1}$ ). All assays were performed within one month after extraction.

Pepsin (EC 3.4.23.1) activity from stomach extracts was determined based on the method of Worthington [22], with some modifications. First, $500 \mu \mathrm{L}$ of $2 \%$ hemoglobin (dissolved in $0.06 \mathrm{~N}$ hydrochloric acid) was mixed with $100 \mu \mathrm{L}$ of crude enzyme extract. The reaction mixture was incubated at $55^{\circ} \mathrm{C}$ for $10 \mathrm{~min}$ and then stopped by adding $1 \mathrm{~mL}$ of $5 \%$ trichloroacetic acid. The mixture was centrifuged at $12,000 \times g$ at room temperature for $5 \mathrm{~min}$. Supernatant was collected and was measured spectrophotometrically at $280 \mathrm{~nm}$. One unit (U) of pepsin activity was defined as 1.0 increase in absorbance at $280 \mathrm{~nm}$.

Trypsin (EC 3.4.21.4) activity from the intestinal extracts was assayed according to Rungruangsak-Torrissen et al. [23], using $N$-benzoyl-L-Arg- $p$-nitroanilide (BAPNA) as the substrates. The assay was performed by mixing $700 \mu \mathrm{L}$ of $0.2 \mathrm{M} \mathrm{Na}_{2} \mathrm{CO}_{3}-\mathrm{NaHCO}_{3}$ buffer (pH 9) containing $1.25 \mathrm{mM}$ BAPNA with $100 \mu \mathrm{L}$ of a crude enzyme extract. The mixture was incubated at $50{ }^{\circ} \mathrm{C}$ for $10 \mathrm{~min}$ and then stopped by adding $800 \mu \mathrm{L}$ of $30 \%$ acetic acid. The absorbance was measured spectrophotometrically at $410 \mathrm{~nm}$ and compared with linear 
range response to $p$-nitroanilide. One unit of trypsin activity was defined as the liberation of $1 \mu \mathrm{mol}$ of $p$-nitroanilide per min.

Amylase activity (EC 3.2.1.1) was determined based on the method of Areekijseree et al. [24], using soluble starch as the substrate. Briefly, $25 \mu \mathrm{L}$ of $5 \%$ soluble starch, $62.5 \mu \mathrm{L}$ of $0.2 \mathrm{M}$ $\mathrm{Na}_{2} \mathrm{HPO}_{4}-\mathrm{NaH}_{2} \mathrm{PO}_{4}$ buffer ( $\mathrm{pH}$ 7), $37.5 \mu \mathrm{L}$ of $20 \mathrm{mM}$ sodium chloride and $125 \mu \mathrm{L}$ of crude enzyme extract were mixed and then incubated at $50{ }^{\circ} \mathrm{C}$ for $15 \mathrm{~min}$. Subsequently, $250 \mu \mathrm{L}$ of $1 \%$ dinitrosalicylic acid was added to stop the enzyme reaction. The color was developed after boiling at $100{ }^{\circ} \mathrm{C}$ for $5 \mathrm{~min}$, cooling to room temperature, and mixing with $2.5 \mathrm{~mL}$ of distilled water. Liberated product was measured spectrophotometrically at $540 \mathrm{~nm}$ against linear range of standard maltose. One unit of amylase activity was defined as the liberation of $1 \mu \mathrm{mol}$ of maltose per min.

Cellulase activity (EC 3.2.1.4) was assayed according to the method of Mendels and Weber [25] with some modifications. The reaction was initiated by mixing $25 \mu \mathrm{L}$ of $2 \%$ carboxymethylcellulose, $62.5 \mu \mathrm{L}$ of $0.2 \mathrm{M} \mathrm{Na}_{2} \mathrm{HPO}_{4}-\mathrm{NaH}_{2} \mathrm{PO}_{4}$ buffer (pH 7) and $37.5 \mu \mathrm{L}$ of $20 \mathrm{mM}$ sodium chloride with $125 \mu \mathrm{L}$ of crude enzyme extract. Enzymatic reaction was incubated at $50^{\circ} \mathrm{C}$ for $15 \mathrm{~min}$, and then stopped by adding $250 \mu \mathrm{L}$ of $1 \%$ dinitrosalicylic acid. The color was developed after boiling at $100{ }^{\circ} \mathrm{C}$ for $5 \mathrm{~min}$, cooling to room temperature and mixing with $2.5 \mathrm{~mL}$ of distilled water. Comparison with the linear range of glucose standards was performed at $540 \mathrm{~nm}$ in order to calculate the enzyme activity. One unit of cellulase activity was defined as the liberation of $1 \mu \mathrm{mol}$ of glucose per min.

Lipase activity (EC 3.1.1.3) was assayed using $p$-nitrophenyl palmitate as substrate, according to the method of Winkler and Stuckmann [26], with some modifications. The reaction mixture contained $200 \mu \mathrm{L}$ of $0.01 \mathrm{M} p$-nitrophenyl palmitate, $800 \mu \mathrm{L}$ of $0.2 \mathrm{M}$ $\mathrm{Na}_{2} \mathrm{HPO}_{4}-\mathrm{NaH}_{2} \mathrm{PO}_{4}$ buffer ( $\left.\mathrm{pH} 8\right)$ and $20 \mu \mathrm{L}$ of crude enzyme extract. The incubation was performed at $60{ }^{\circ} \mathrm{C}$ for $30 \mathrm{~min}$ and then stopped by adding $250 \mu \mathrm{L}$ of $1 \mathrm{M}$ sodium carbonate. The supernatant collection was performed after centrifugation at $13,000 \times g$ for $15 \mathrm{~min}$ at $4{ }^{\circ} \mathrm{C}$. The liberated product was measured spectrophotometrically at $410 \mathrm{~nm}$ and referenced to the linear range of $p$-nitrophenol standard. One unit of lipase activity was defined as the liberation of $1 \mu \mathrm{mol}$ of $p$-nitrophenol per min.

\subsection{Flesh Quality}

\subsubsection{Protein Synthesis Capacity}

RNA and protein concentrations were determined as described by RungruangsakTorrissen et al. [23]. Briefly, fifty milligrams of frozen white muscle were mixed with TRIzol $^{\circledR}$ reagent (Invitrogen, Carlsbad, CA, USA) and sonicated (VCX; Sonic and Materials Inc., Newtown, CT, USA) to obtain a pink transparent solution. The mixture was mixed with chloroform and then centrifuged to obtain upper (RNA) and lower (protein) phases. Isopropanol and ethanol were used to precipitate these phases. The RNA sediments were dissolved in sodium acetate and dried at $55{ }^{\circ} \mathrm{C}$ while sodium dodecyl sulfate was applied to the protein sediments. RNA and protein concentrations were measured spectrophotometrically at 260 and $280 \mathrm{~nm}$. The measured absorbances were calculated to the concentrations of RNA and protein from the equations $E_{260}=40 \mu \mathrm{g} \mathrm{mL} \mathrm{L}^{-1}$ and $E_{280}=2.1 \mathrm{mg} \mathrm{mL}^{-1}$, respectively.

\subsubsection{Enthalpy of Actin and Myosin}

Ten milligrams of defrosted white muscle were heated in a differential scanning calorimeter (DSC7; Perkin Elmer, Waltham, MA, USA) from $20{ }^{\circ} \mathrm{C}$ to $100{ }^{\circ} \mathrm{C}$ at a rate of $10^{\circ} \mathrm{C} \mathrm{min}^{-1}$. The enthalpic response $(\Delta \mathrm{H})$ was automatically recorded to identify actin and myosin based on onset $\left(\mathrm{T}_{\mathrm{o}}\right.$, peak $\left(\mathrm{T}_{\mathrm{p}}\right)$ and conclusion $\left(\mathrm{T}_{\mathrm{c}}\right)$ temperatures, as reported by Nonthaput et al. [27].

\subsection{Carcass Composition Analysis}

Whole fish were minced and analyzed for moisture, crude protein, crude lipid and crude ash, according to standard methods of AOAC [20]. 


\subsection{Hematological Determinations}

Blood suspension was prepared [28], and red (RBC) and white (WBC) blood cells were counted with a hemacytometer (Precicolor; HBG, Giessen-Luetzellinden, Germany) under a compound microscope. Hemoglobin $(\mathrm{Hb})$ and hematocrit $(\mathrm{Hct})$ were determined by measuring the formation of cyanmethemoglobin [29] and by using laboratory-prepared capillary tubes treated with 10\% heparin [30], respectively. Differential leucocytes were counted from dried blood smears after fixing with methanol and staining with JennerGiemsa. Heparinized blood samples were centrifuged at $2000 \times g$ for $10 \mathrm{~min}$ at $4{ }^{\circ} \mathrm{C}$ for preparing fish plasma. The plasma protein was determined according to Lowry et al. [21] using BSA as protein standard. Some blood samples were added into non-EDTA tube (nonethylenediaminetetraacetate) and allowed to clot at $4{ }^{\circ} \mathrm{C}$. The serum samples were kept after centrifugation at $3000 \times g$ for $10 \mathrm{~min}$ at $4{ }^{\circ} \mathrm{C}$. Blood urea nitrogen (BUN), creatinine, uric acid, alkaline phosphatase (ALP) and aspartate aminotransaminase (AST) were determined from the serum samples using a commercial diagnostic kit (PZ Cormay S.A. Company, Lomianki, Poland). Mean cell volume (MCV), mean cell hemoglobin (MCH) and mean cell hemoglobin concentration (MCHC) were calculated as described by Javed et al. [31]:

$$
\begin{gathered}
\mathrm{MCV}(\mathrm{fL})=10 \times\left[\operatorname{Hct}(\%) / \mathrm{RBC}\left(\times 10^{6} \text { cells } \mu \mathrm{L}^{-1}\right)\right] \\
\mathrm{MCH}(\mathrm{pg})=10 \times\left[\mathrm{Hb}\left(\mathrm{g} \mathrm{dL}^{-1}\right) / \mathrm{RBC}\left(\times 10^{6} \text { cells } \mu \mathrm{L}^{-1}\right)\right] \\
\mathrm{MCHC}\left(\mathrm{g} \mathrm{dL}^{-1}\right)=100 \times\left[\mathrm{Hb}\left(\mathrm{g} \mathrm{dL}^{-1}\right) / \operatorname{Hct}(\%)\right]
\end{gathered}
$$

\subsection{Liver Histological Examination}

Fish liver was collected and examined for histological study using the standard method of Suvarna et al. [32]. After fixation in 10\% neutral-buffered formalin and dehydrated through in an ascending ethanol series $(70 \%, 95 \%$ and $100 \%)$, the samples were embedded in paraffin and 3-5 $\mu \mathrm{m}$ longitudinal sections were cut using a tissue microtome. Liver histology was examined under a light microscope after staining with hematoxylin and eosin ( $\mathrm{H} \& \mathrm{E})$.

\subsection{Statistical Analysis}

Data are expressed as mean \pm standard error of mean (SEM). All the data were analyzed using SPSS version 17 software (SPSS Inc., Chicago, IL, USA). Arcsine transformation was applied to transform the variables that are percentages. One-way analysis of variance was used, and the mean comparisons were carried out using Duncan's multiple range test as a post-hoc test at a significance level of $\alpha=0.05(p<0.05)$.

\section{Results}

\subsection{Chemical Compositions of PKM and FPKM}

Fermentation of PKM with EM improved the amount of crude protein (20.79\%), NFE $(40.07 \%)$ and GE (19.58\%) while crude lipid (15.65\%), crude fiber (36.45\%) and ash (29.54\%) were decreased (Table 2).

Table 2. Proximate chemical compositions (\% of dry matter) of PKM and FPKM. The data given are means from duplicate analysis.

\begin{tabular}{ccc}
\hline Composition & PKM & FPKM \\
\hline Crude protein (\%) & 13.13 & 15.86 \\
Crude lipid (\%) & 9.14 & 7.71 \\
Crude fiber (\%) & 38.74 & 24.62 \\
Ash (\%) & 4.03 & 2.84 \\
NFE (\%) & 34.96 & 48.97 \\
GE $\left(\mathrm{kJ} \mathrm{g}^{-1}\right)$ & 12.72 & 15.21 \\
\hline
\end{tabular}

PKM, palm kernel meal; FPKM, fermented palm kernel meal; NFE, nitrogen-free extract; GE, gross energy. 


\subsection{Survival, Growth and Feed Consumption}

No significant differences in survival (93\% on average) were observed across the five dietary treatments $(p>0.05$, Table 3$)$. Fish fed 50FPKM only presented significant differences from the other treatments in terms of final body weight (and total length with fish fed 25FPKM), although the DGC was not significantly different. Fish fed 25FPKM diet had significantly highest $K$ values relative to the other treatments, except for fish fed 50FPKM diet. Feed utilization parameters (FR, FCR and PER) were also similar across the five alternative treatments.

Table 3. Survival, growth performance and feed utilization of sex-reversed red tilapia fed with experimental diets containing varying levels of FPKM for 12 weeks.

\begin{tabular}{|c|c|c|c|c|c|c|}
\hline Parameter & OFPKM & 25FPKM & 50FРКМ & 75FPKM & 100FPKM & $p$-Value \\
\hline Survival (\%) & $93.13 \pm 1.57$ & $91.88 \pm 1.20$ & $95.00 \pm 1.44$ & $92.50 \pm 2.70$ & $92.50 \pm 1.02$ & 0.733 \\
\hline Average initial weight (g) & $14.66 \pm 0.37$ & $15.13 \pm 1.23$ & $14.60 \pm 0.60$ & $15.05 \pm 0.25$ & $14.81 \pm 0.56$ & 0.975 \\
\hline Average final weight $(\mathrm{g})$ & $74.99 \pm 1.51^{b}$ & $75.77 \pm 1.88^{b}$ & $81.42 \pm 0.72^{a}$ & $76.38 \pm 1.32^{b}$ & $77.18 \pm 0.82^{b}$ & 0.029 \\
\hline Total length $(\mathrm{cm})$ & $17.59 \pm 0.27^{\mathrm{a}}$ & $15.08 \pm 0.29^{c}$ & $16.56 \pm 0.38^{a b}$ & $16.41 \pm 0.35^{b}$ & $16.39 \pm 0.52^{b}$ & 0.001 \\
\hline$K$ & $1.30 \pm 0.01^{\mathrm{b}}$ & $2.04 \pm 0.17^{\mathrm{a}}$ & $1.68 \pm 0.12^{a b}$ & $1.58 \pm 0.02^{b}$ & $1.57 \pm 0.16^{\mathrm{b}}$ & 0.047 \\
\hline DGC $\left(\%\right.$ BW day $\left.{ }^{-1}\right)$ & $2.16 \pm 0.05$ & $2.10 \pm 0.09$ & $2.25 \pm 0.04$ & $2.11 \pm 0.03$ & $2.15 \pm 0.03$ & 0.317 \\
\hline FR (\% BW day $\left.{ }^{-1}\right)$ & $2.42 \pm 0.11$ & $2.48 \pm 0.05$ & $2.28 \pm 0.06$ & $2.46 \pm 0.08$ & $2.43 \pm 0.03$ & 0.301 \\
\hline FCR (g feed g gain $\left.{ }^{-1}\right)$ & $1.70 \pm 0.08$ & $1.64 \pm 0.09$ & $1.71 \pm 0.09$ & $1.69 \pm 0.07$ & $1.83 \pm 0.08$ & 0.635 \\
\hline PER (g gain g protein ${ }^{-1}$ ) & $1.93 \pm 0.10$ & $2.06 \pm 0.11$ & $1.93 \pm 0.11$ & $1.97 \pm 0.08$ & $1.83 \pm 0.08$ & 0.584 \\
\hline
\end{tabular}

FPKM, fermented palm kernel meal; K, Fulton's condition factor; DGC, daily growth coefficient; BW, body weight; FR, feeding rate; FCR, feed conversion ratio; PER, protein efficiency ratio. Data are expressed as mean \pm SEM of all fish in three replications. Significant differences in each row are indicated by different superscripts $(p<0.05)$.

\subsection{Digestive Enzyme Specific Activities}

Different trends were observed for the digestive enzymes across the five dietary treatments (Table 4). Fish fed 50FPKM and 75FPKM diets had the highest pepsin specific activities relative among the treatments $(p<0.05)$. Trypsin specific activity was highest in the fish fed with the full replacement of SBM by FPKM, followed by the 50\% replacement. There was no effect from replacement of SBM by FPKM on the specific activity of amylase. The fish fed 75FPKM and 100FPKM diets had the highest cellulase and lipase activities, while the remaining treatments were mutually rather similar.

Table 4. Digestive enzyme activity of sex-reversed red tilapia fed with experimental diets containing varying levels of FPKM for 12 weeks.

\begin{tabular}{|c|c|c|c|c|c|c|}
\hline Digestive Enzyme & 0FPKM & 25FPKM & 50FРКМ & 75FPKM & 100FPKM & $p$-Value \\
\hline Pepsin (U mg protein $\left.{ }^{-1}\right)$ & $0.50 \pm 0.10^{b}$ & $0.60 \pm 0.19^{b}$ & $1.42 \pm 0.17^{\mathrm{a}}$ & $1.24 \pm 0.15^{\mathrm{a}}$ & $0.46 \pm 0.13^{b}$ & $<0.001$ \\
\hline Trypsin (mU mg protein $\left.{ }^{-1}\right)$ & $165.34 \pm 8.21^{\mathrm{c}}$ & $158.09 \pm 10.48^{c}$ & $205.98 \pm 12.29^{b}$ & $142.60 \pm 18.05^{\mathrm{c}}$ & $258.27 \pm 17.77^{\mathrm{a}}$ & $<0.001$ \\
\hline Amylase (U mg protein ${ }^{-1}$ ) & $59.25 \pm 2.58$ & $52.96 \pm 2.11$ & $55.62 \pm 2.74$ & $61.93 \pm 3.57$ & $52.14 \pm 2.03$ & 0.056 \\
\hline Cellulase (U mg protein ${ }^{-1}$ ) & $227.70 \pm 11.21^{\mathrm{c}}$ & $241.09 \pm 16.41^{\mathrm{c}}$ & $265.18 \pm 16.01 b c$ & $268.56 \pm 18.24^{\mathrm{ab}}$ & $314.83 \pm 10.18^{a}$ & 0.002 \\
\hline Lipase (mU mg protein $\left.{ }^{-1}\right)$ & $42.00 \pm 3.41^{b}$ & $40.72 \pm 3.75^{b}$ & $45.11 \pm 2.31^{b}$ & $61.00 \pm 2.64^{\mathrm{a}}$ & $53.95 \pm 3.22^{a b}$ & 0.012 \\
\hline
\end{tabular}

FPKM, fermented palm kernel meal. Data are expressed as mean \pm SEM $(n=9)$. Significant differences in each row are indicated by different superscripts $(p<0.05)$.

\subsection{Flesh Quality}

RNA concentrations had the highest values in the fish fed OFPKM, 25FPKM and 50FPKM diets, while significantly increased protein concentrations were observed in fish fed 50FPKM diet relative to the control treatment (Table 5). The RNA/protein ratio (protein synthesis) was highest in the fish fed OFPKM and was significantly decreased in the fish fed FPKM-containing diets, except for fish fed the 25FPKM diet. The $\Delta \mathrm{H}$ of myosin, actin, and their sum were similar across the five dietary treatments, while the $\Delta \mathrm{H}$ ratio of actin to myosin was significantly decreased in the fish fed the 75FPKM diet from that with the control diet. 
Table 5. Protein synthesis capacity and amount of myosin and actin in white muscle of sex-reversed red tilapia observed at the end of 12 weeks of dietary treatment.

\begin{tabular}{|c|c|c|c|c|c|c|}
\hline Flesh Parameter & 0FPКМ & 25FPKM & 50FPKM & 75FPKM & 100FPKM & $p$-Value \\
\hline RNA $\left(\mu g g^{-1}\right)$ & $3,612 \pm 123^{a}$ & $3,614 \pm 93^{a}$ & $3,604 \pm 141^{\mathrm{a}}$ & $3,052 \pm 113^{b}$ & $3,077 \pm 171^{b}$ & 0.002 \\
\hline Protein $\left(\mathrm{mg} \mathrm{g}^{-1}\right)$ & $199.97 \pm 16.45^{b}$ & $221.65 \pm 12.19^{a b}$ & $240.51 \pm 7.26^{a}$ & $197.58 \pm 7.69^{b}$ & $216.25 \pm 12.91^{\mathrm{ab}}$ & 0.046 \\
\hline $\mathrm{RNA} /$ protein ratio $\left(\mu \mathrm{g} \mathrm{mg} \mathrm{m}^{-1}\right)$ & $18.74 \pm 1.64^{\mathrm{a}}$ & $16.54 \pm 0.81^{\mathrm{ab}}$ & $15.12 \pm 0.80^{b}$ & $14.43 \pm 1.12^{b}$ & $14.45 \pm 0.93^{b}$ & 0.045 \\
\hline$\Delta \mathrm{H}_{\mathrm{Myosin}}\left(\mathrm{J} \mathrm{g}^{-1}\right)$ & $0.67 \pm 0.08$ & $0.57 \pm 0.03$ & $0.80 \pm 0.19$ & $0.80 \pm 0.07$ & $0.68 \pm 0.07$ & 0.485 \\
\hline$\Delta \mathrm{H}_{\text {Actin }}\left(\mathrm{J} \mathrm{g}^{-1}\right)$ & $0.34 \pm 0.00$ & $0.23 \pm 0.03$ & $0.34 \pm 0.07$ & $0.25 \pm 0.05$ & $0.31 \pm 0.01$ & 0289 \\
\hline$\Delta \mathrm{H}_{\mathrm{Myosin}}+\operatorname{Actin}\left(\mathrm{J} \mathrm{g}^{-1}\right)$ & $1.07 \pm 0.07$ & $0.81 \pm 0.06$ & $0.97 \pm 0.20$ & $1.06 \pm 0.10$ & $1.07 \pm 0.08$ & 0.330 \\
\hline$\Delta$ Actin/myosin ratio & $0.58 \pm 0.06^{\mathrm{a}}$ & $0.41 \pm 0.03^{\mathrm{ab}}$ & $0.54 \pm 0.01^{\mathrm{a}}$ & $0.32 \pm 0.06^{b}$ & $0.47 \pm 0.06^{\mathrm{ab}}$ & 0.050 \\
\hline
\end{tabular}

FPKM, fermented palm kernel meal; $\Delta \mathrm{H}$, protein denaturation enthalpy. Data are expressed as mean $\pm \operatorname{SEM}(n=9)$. Significant differences in each row are indicated by different superscripts $(p<0.05)$.

\subsection{Carcass Composition}

At the end of experiment, the carcass moisture, crude protein, crude lipid and ash did not differ across the five dietary treatments (Table 6).

Table 6. Whole body composition (\% of wet weight basis) of sex-reversed red tilapia fed with experimental diets containing varying levels of FPKM for 12 weeks.

\begin{tabular}{ccccccc}
\hline Composition (\%) & 0FPKM & 25FPKM & 50FPKM & 75FPKM & 100FPKM & $p$-Value \\
\hline Moisture & $67.48 \pm 0.77$ & $66.71 \pm 0.68$ & $68.15 \pm 0.85$ & $67.29 \pm 0.72$ & $67.96 \pm 0.71$ & 0.719 \\
Crude protein & $17.26 \pm 0.10$ & $13.09 \pm 4.58$ & $15.30 \pm 1.72$ & $17.64 \pm 0.44$ & $18.49 \pm 0.32$ & 0.465 \\
Crude lipid & $5.94 \pm 0.72$ & $6.42 \pm 0.54$ & $4.77 \pm 0.60$ & $4.88 \pm 0.59$ & $5.17 \pm 0.62$ & 0.309 \\
Ash & $4.99 \pm 0.35$ & $5.45 \pm 0.52$ & $5.26 \pm 0.60$ & $5.59 \pm 0.40$ & $5.72 \pm 0.47$ & 0.795 \\
\hline
\end{tabular}

FPKM, fermented palm kernel meal. Data are expressed as mean \pm SEM $(n=9)$. Significant differences in each row are indicated by different superscripts $(p<0.05)$.

\subsection{Hematological Parameters}

WBC was comparatively high in the fish fed with diets replacing at least $50 \%$ of SBM by FPKM, relative to the other treatment groups (Table 7). Significantly decreased MCHC was only observed in the fish fed the 75FPKM diet, relative to the other treatments, except for 50FPKM. Partial or full replacement of SBM by FPKM can significantly increase plasma protein. Except for the above parameters, the other hematological assays were very similar across the five dietary treatments.

Table 7. Hematological parameters of sex-reversed red tilapia fed with experimental diets containing varying levels of FPKM for 12 weeks.

\begin{tabular}{|c|c|c|c|c|c|c|}
\hline Hematological Parameter & 0FPKM & 25FPKM & 50FPKM & 75FPKM & 100FPKM & $p$-Value \\
\hline $\operatorname{RBC}\left(\times 10^{6}\right.$ cells $\left.\mu \mathrm{L}^{-1}\right)$ & $1.95 \pm 0.07$ & $1.95 \pm 0.13$ & $2.05 \pm 0.07$ & $2.04 \pm 0.05$ & $2.00 \pm 0.13$ & 0.901 \\
\hline WBC $\left(\times 10^{4}\right.$ cells $\left.\mu \mathrm{L}^{-1}\right)$ & $37.33 \pm 2.52^{b}$ & $38.37 \pm 4.48^{b}$ & $55.67 \pm 2.73^{a}$ & $52.90 \pm 1.87^{\mathrm{a}}$ & $59.20 \pm 4.42^{\mathrm{a}}$ & 0.002 \\
\hline $\mathrm{Hb}\left(\mathrm{g} \mathrm{dL}^{-1}\right)$ & $7.33 \pm 0.18$ & $7.60 \pm 0.44$ & $7.78 \pm 0.23$ & $7.78 \pm 0.23$ & $7.33 \pm 0.25$ & 0.637 \\
\hline Hematocrit (\%) & $28.88 \pm 0.64$ & $29.93 \pm 1.75$ & $30.83 \pm 0.93$ & $31.05 \pm 0.96$ & $28.88 \pm 1.09$ & 0.526 \\
\hline $\mathrm{MCH}\left(\mathrm{pg}\right.$ cell $\left.^{-1}\right)$ & $37.70 \pm 0.40$ & $39.08 \pm 0.61$ & $37.98 \pm 0.86$ & $38.05 \pm 0.50$ & $38.50 \pm 0.31$ & 0.517 \\
\hline $\mathrm{MCHC}\left(\mathrm{g} \mathrm{dL}^{-1}\right)$ & $25.35 \pm 0.06^{\mathrm{a}}$ & $25.40 \pm 0.06^{\mathrm{a}}$ & $25.20 \pm 0.07^{a b}$ & $25.05 \pm 0.05^{b}$ & $25.38 \pm 0.11^{a}$ & 0.021 \\
\hline $\mathrm{MCV}(\mathrm{fL})$ & $148.50 \pm 1.85$ & $154.00 \pm 2.71$ & $150.75 \pm 3.25$ & $152.00 \pm 2.12$ & $151.67 \pm 1.86$ & 0.618 \\
\hline Lymphocyte (\%) & $90.33 \pm 1.45$ & $77.33 \pm 9.82$ & $73.25 \pm 8.16$ & $81.75 \pm 3.09$ & $82.00 \pm 4.55$ & 0.437 \\
\hline Monocyte (\%) & $4.50 \pm 1.19$ & $6.50 \pm 1.19$ & $6.00 \pm 1.47$ & $4.00 \pm 0.58$ & $5.75 \pm 1.75$ & 0.694 \\
\hline Neutrophil $(\%)$ & $17.50 \pm 11.86$ & $25.00 \pm 12.21$ & $20.75 \pm 6.77$ & $12.00 \pm 3.94$ & $12.25 \pm 5.36$ & 0.799 \\
\hline Plasma protein $\left(\mathrm{g} \mathrm{dL}^{-1}\right)$ & $1.44 \pm 0.13^{\mathrm{c}}$ & $2.13 \pm 0.13^{b}$ & $2.03 \pm 0.05^{b}$ & $1.91 \pm 0.11^{\mathrm{b}}$ & $2.54 \pm 0.12^{\mathrm{a}}$ & $<0.001$ \\
\hline BUN $\left(\mathrm{mg} \mathrm{dL}^{-1}\right)$ & $6.50 \pm 1.55$ & $6.00 \pm 1.35$ & $5.75 \pm 1.25$ & $2.67 \pm 0.33$ & $4.75 \pm 1.31$ & 0.365 \\
\hline Creatinine $\left(\mathrm{mg} \mathrm{dL}^{-1}\right)$ & $0.46 \pm 0.37$ & $0.24 \pm 0.08$ & $0.64 \pm 0.28$ & $0.59 \pm 0.21$ & $0.30 \pm 0.12$ & 0.696 \\
\hline Uric acid $\left(\mathrm{mg} \mathrm{dL}^{-1}\right)$ & $0.85 \pm 0.59$ & $1.25 \pm 0.62$ & $1.48 \pm 1.09$ & $0.23 \pm 0.05$ & $0.63 \pm 0.28$ & 0.655 \\
\hline $\operatorname{ALP}\left(\mathrm{U} \mathrm{L}^{-1}\right)$ & $39.33 \pm 7.97$ & $33.00 \pm 4.06$ & $29.25 \pm 5.04$ & $29.33 \pm 2.85$ & $25.67 \pm 5.78$ & 0.509 \\
\hline AST $\left(\mathrm{U} \mathrm{L}^{-1}\right)$ & $124.33 \pm 12.57$ & $92.67 \pm 9.91$ & $128.50 \pm 17.50$ & $114.67 \pm 5.50$ & $70.00 \pm 14.74$ & 0.181 \\
\hline
\end{tabular}

FPKM, fermented palm kernel meal; RBC, red blood cells; WBC, white blood cells; $\mathrm{Hb}$, hemoglobin; $\mathrm{MCH}$, mean corpuscular hemoglobin; $\mathrm{MCHC}$, mean corpuscular hemoglobin concentration; MCV, mean corpuscular volume; BUN, blood urea nitrogen; ALP, alkaline phosphatase; AST, aspartate aminotransferase. Data are expressed as mean $\pm \operatorname{SEM}(n=9)$. Significant differences in each row are indicated by different superscripts $(p<0.05)$. 


\subsection{Liver Histoarchitecture}

Sex-reversed red tilapia fed with an FPKM-free diet (Figure 1a) and with the FPKMcontaining diets (Figure $1 \mathrm{~b}-\mathrm{e}$ ) exhibited normal-shaped hepatocytes and clearly located cell nuclei. There were no signs of necrosis or inflammation in any fish.
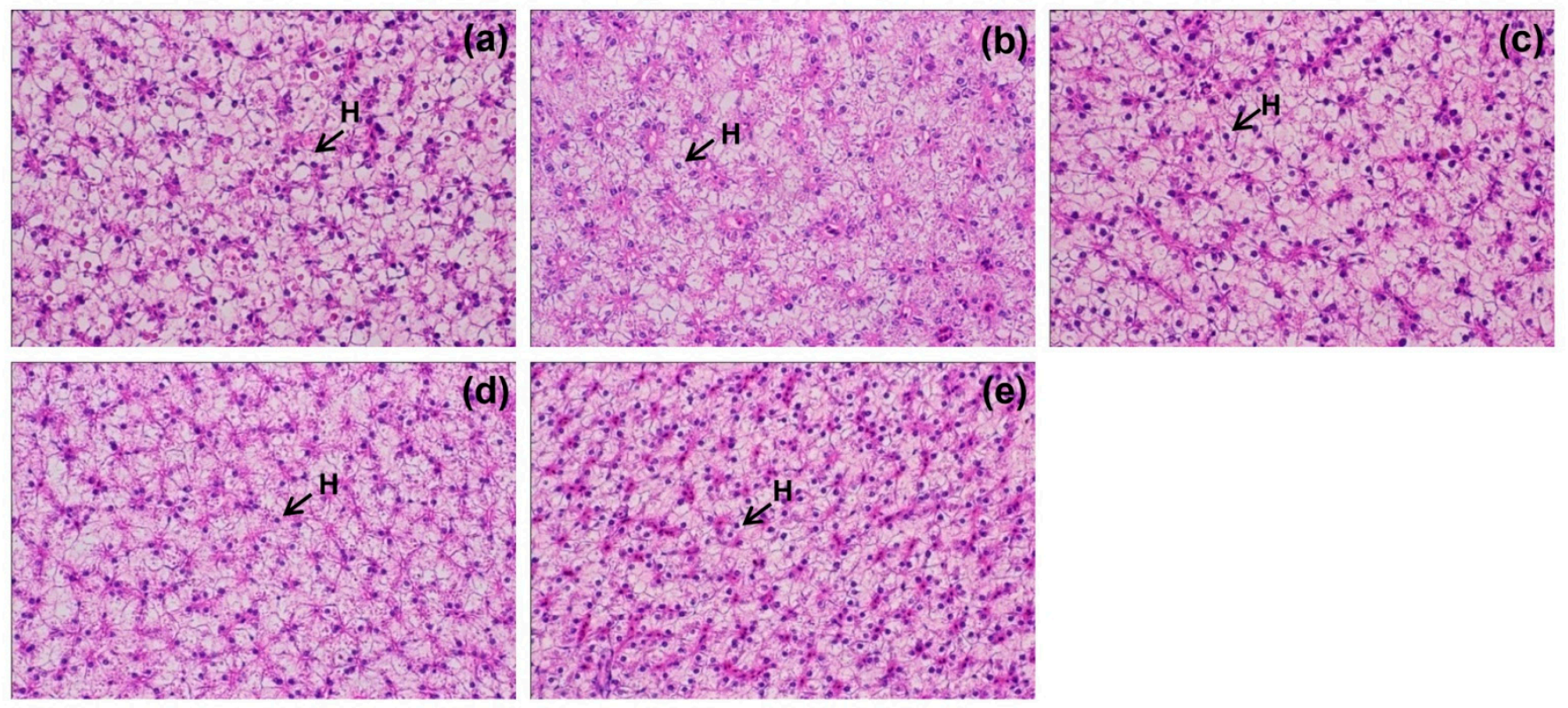

$\overline{10 \mu \mathrm{m}}$

Figure 1. The microanatomy in longitudinal section of liver for sex-reversed red tilapia fed with 0FPKM (a), 25FPKM (b), 50FPKM (c), 75FPKM (d) and 100FPKM (e) for 12 weeks. Images were taken at $400 \times$ magnification and the tissues were stained by hematoxylin and eosin (H\&E). $\mathrm{H}$ indicates hepatocyte.

\section{Discussion}

Fermentation of plant by-products with beneficial microorganisms has been adopted to improve the nutritional quality of feedstuffs by the action of enzymes from bacteria, yeasts and molds. Increased protein in FPKM in the current study could be due to the secretion of enzymes or to the release of bound proteins by the breakdown of protein complexes. This presumption is in agreement with increasing protein content in FPKM after conducting spontaneous fermentation for one week $(23.42 \%)$ relative to raw PKM $(20.04 \%)$ [33]. It is possible that the replacement of bound proteins from SBM in the current study by amino acids or small proteins from FPKM might improve the diet quality, although the experimental diets were isonitrogenous. In palm kernel cake, a slight increase in protein content (16.43\% vs. $16.80 \%)$ and significantly improved amino acid profiles have also been observed when fermented with Paenibacillus polymyxa ATCC 842: isoleucine $(0.50 \%$ vs. $0.59 \%)$, phenylalanine $(0.57 \%$ vs. $0.66 \%)$, threonine $(0.41 \%$ vs. $0.51 \%)$, histidine $(0.23 \%$ vs. $0.29 \%)$, methionine $(0.22 \%$ vs. $0.27 \%)$, arginine $(1.60 \%$ vs. $1.76 \%)$, glycine $(0.60 \%$ vs. $0.78 \%)$, aspartic acid (1.12\% vs. $1.27 \%)$, glutamic acid $(2.48 \%$ vs. $2.80 \%)$, proline $(0.44 \%$ vs. $0.59 \%)$ and serine ( $0.56 \%$ vs. $0.69 \%$ ) [34]. The cell wall constituents and non-starch polysaccharides (NSP) contribute $73 \%$ and $75 \%$ of raw PKM, respectively [35]. Significantly decreased crude fiber was not surprising since the EM contained cellulolytic microorganisms providing high cellulase activity [36]. Fluctuation in the amount of this indigestible element can increase the digestible carbohydrates, NFE. Fermentation of a medicinal plant with Lactobacillus plantarum and Saccharomyces cerevisiae can reduce the amount of saturated fatty acids [37]. Decreased lipid content in the current study is possible since the fatty acids in PKM are mainly in saturated forms. Regarding ash, the reduction in FPKM when compared with non-fermented PKM might be caused by the high capacity to utilize the constituent minerals during fermentation [38]. 
Various plant by-products have been used to replace protein from SBM in fish diets. In hybrid tilapia $(O$. niloticus $\times O$. aureus), $60 \%$ replacement of SBM by cottonseed meal in diets was optimal [5]. Thirty percent replacement of SBM by rubber seed meal was also suitable for the same species [39], similar to the replacement by faba beans at $24 \%$ in O. niloticus diet [40], while $50 \%$ replacement level was suitable by cottonseed meal in diets for channel catfish, Ictalurus puctatus [41]. In the current study, sex-reversed red tilapia fed a 50FPKM diet were superior in growth performance, while the feed utilization parameters were similar to the other treatments. However, higher replacement than the optimal level tends to provide adverse effects on growth, feed utilization and health status in several fish species.

Proteolytic activities were investigated through the digestive enzymes, which are mainly present in the stomach (pepsin) and the intestine (trypsin). That the highest overall specific activity was in fish fed the 50FPKM diet, followed by 75FPKM, indicating high capacity to utilize protein from diets. Generally, native PKM contains a large fraction of NSPs and these cell wall constituents inhibit nutrient utilization by encapsulating them in the gastrointestinal tract $[35,42]$. Significant increase in trypsin specific activity alone, in the fish fed the full replacement diet, might be due to overproduction of enzymes to achieve sufficient protein utilization [43], since approximately $40-50 \%$ of the ingested dietary proteins are digested by trypsin [44]. The amylase specific activity was unaffected by the replacement level of SBM by FPKM in the current study, indicating that this omnivorous fish had sufficient access to carbohydrate digestion. Generally, glucose is the primary energy source for a number of tissues [45], so maintenance of its metabolic homeostasis is important. Activity of cellulase increased with the replacement level by FPKM. The up-regulation of this enzyme activity might improve the bioavailability of fiber along the alimentary tract of the reared fish. Lipase activity was generally similar, except in the 75FPKM treatment group. Fluctuation in the fatty acid profiles or their content may alter the lipid utilization. Based on the overall enzyme specific activities, the maintenance of feed utilization parameters (FR, FCR and PER) in the fish fed 75FPKM or 100FPKM diets might consider a protein-sparing effect from cellulose and lipid digestion, as indicated by increased specific activities of fiber- and lipid-digesting enzymes.

White muscle is significantly responsible for metabolism and protein growth [46]. High concentrations of RNA and protein and low protein synthesis capacity (RNA/protein ratio) indicate superior growth performance [18,47] of the fish fed the 50FPKM diet. The quality of flesh actin and myosin was also investigated in the current study. The enthalpy response is associated with the amount of protein left in its native state [48]. Maintaining the four observed enthalpy parameters also supports unchanged quality of the main muscle proteins across the five dietary treatments, except in the fish fed the 75FPKM diet. In addition, no differences were observed in whole carcass composition. This indicates that the fish can defend their composition in the face of feedstuff replacement, which appears to be more important than accelerating growth (DGC) or feed utilization (FR, FCR and PER) [43].

Three hematological parameters of the overall sixteen items were affected by the replacement of SBM with FPKM. At least 50\% replacement can significantly increase WBC. This increment is associated with lymphopoiesis stimulation, as the leucocytes are the nonspecific immune system in fish [49]. The $\beta$-glucan from yeast cell wall and Bacillus sp. in the EM may act as prebiotics and probiotics, respectively, stimulating the fish immune response. Our results are in agreement with those from replacing SBM with 10-30\% rubber seed meal in the diet of rohu fingerlings, Labeo rohita [50], or replacement with 15-30\% cottonseed meal in the diet of hybrid tilapia [5]. Plasma protein also increased in a replacement leveldependent manner. Fermentation by the EMs might provide easily digested protein to the feed, or a high amount of fish meal can enhance protein digestibility [51], with digestion mainly by trypsin. Replacement of highly digestible fish meal by poorly digestible plant mixtures (corn gluten, wheat gluten, extruded peas, rapeseed meal and sweet white lupin) can consequently decrease the plasma protein level in gilthead sea bream, Sparus aurata [52]. 
The slight changes in the current study are within the standard range of healthy fish, suggesting no negative effects on health status by the preferred treatment. This lack of negative effects is also supported by the unchanged liver histoarchitectures of fish fed the 50FPKM diet (or any of the other treatments tested).

\section{Conclusions}

The nutritive value of palm kernel meal was improved by solid-state fermentation with effective microorganisms. This fermented feedstuff could be used to replace soybean meal at $50 \%$, as indicated by superior growth performance and maintained feed utilization. Some improvements in digestive enzyme activities and flesh protein synthesis capacity were observed, while no negative effects on carcass composition, hematological parameters or liver histoarchitecture also supported this replacement level of soybean meal with fermented palm kernel meal for the reared fish. The low current purchasing price of fermented palm kernel meal (0.32 USD kg-1) relative to soybean meal $\left(0.57 \mathrm{USD} \mathrm{kg}{ }^{-1}\right)$ supports its use for economic benefits. Findings from the current study support the use of fermented palm kernel meal in aquafeed production, providing a low-cost diet for tilapia farming.

Author Contributions: Conceptualization, W.W. and K.T.; methodology, W.W., K.T., W.H. and N.S.; validation, W.W. and K.T.; formal analysis, W.W., K.T., W.H. and N.S.; investigation, W.W., K.T., W.H. and N.S.; resources, W.W. and K.T.; data curation, W.W. and K.T.; writing—original draft preparation, W.W. and K.T.; writing-review and editing, W.W., K.T. and N.S.; supervision, W.W. and K.T.; project administration, W.W. and K.T.; funding acquisition, W.W. and K.T. All authors have read and agreed to the published version of the manuscript.

Funding: This research was funded by the National Research Council, Thailand (Contract No. 2560A17102171).

Institutional Review Board Statement: The preparation, husbandry, feeding trial and sampling of animals conformed to the "Ethical Principles and Guidelines for the Use of Animals for Scientific Purposes", National Research Council, Thailand (Application No. UI-02771-2559 and U1-06514-2560).

Informed Consent Statement: Not applicable.

Data Availability Statement: Data are available on request from the authors.

Acknowledgments: The authors thank Wongkot Phuphumirat for excellent technical help; and Seppo Karrila and the Publication Clinic, Research and Development Office, Prince of Songkla University, for advice in manuscript preparation.

Conflicts of Interest: The authors declare no conflict of interest.

\section{References}

1. FAO. Available online: http://www.fao.org/fishery/culturedspecies/Oreochromis_niloticus/en (accessed on 1 June 2021).

2. $\quad$ El-Sayed, A.F.M. Tilapia Culture; CABI Publishing: Wallingford, UK, 2006; pp. 1-24.

3. Manosroi, J.; Petchjul, K.; Manosroi, A. Effect of fluoxymesterone fish feed granule on sex reversal of the hybrid, Thai red tilapia (Oreochromis niloticus Linn. $\times$ Oreochromis mossambicus Linn.). Asian Fish. Sci. 2004, 17, 323-331.

4. El-Saidy, D.M.S.D.; Gaber, M.M.A. Replacement of fish meal with a mixture of different plant protein sources in juvenile Nile tilapia, Oreochromis niloticus (L.) diets. Aquac. Res. 2003, 34, 1119-1127. [CrossRef]

5. Yue, Y.; Zhou, Q. Effect of replacing soybean meal with cottonseed meal on growth, feed utilization, and hematological indexes for juvenile hybrid tilapia, Oreochromis niloticus $\times$ O. aureus.. Aquaculture 2008, 284, 185-189. [CrossRef]

6. Plaipetch, P.; Yakupitiyage, A. Effect of replacing soybean meal with yeast-fermented canola meal on growth and nutrient. retention of Nile tilapia, Oreochromis niloticus (Linnaeus 1758). Aquac. Res. 2014, 45, 1744-1753. [CrossRef]

7. Hossain, M.A.; Islam, S.F. Meat and bone meal as partial substitute for fish meal in nursery diet for giant freshwater prawn, Macrobrachium rosenbergii (deMan). J. World Aquac. Soc. 2007, 38, 272-280. [CrossRef]

8. Wattanakul, W.; Wattanakul, U.; Thongprajukaew, K.; Muenpo, C. Fish condensate as effective replacer of fish meal protein for striped snakehead, Channa striata (Bloch). Fish Physiol. Biochem. 2017, 43, 217-228. [CrossRef]

9. Storebakken, T.; Refstie, S.; Ruyter, B. Soy products as fat and protein sources in fish diets for intensive aquaculture. In Soy in Animal Nutrition; Drackley, J.K., Ed.; Federation of Animal Science Societies: Savoy, IL, USA, 2000; pp. 127-170. 
10. Lim, S.J.; Lee, K.J. Partial replacement of fish meal by cottonseed meal and soybean meal with iron and phytase supplementation for parrot fish Oplegnathus fasciatus. Aquaculture 2009, 290, 283-289. [CrossRef]

11. Sindhu, A.A.; Khan, M.A.; Nisa, M.U.; Sarwar, M. Agro-industrial by-products as a potential source of livestock feed. Int. J. Agric. Biol. 2002, 4, 307-310.

12. Drew, M.D.; Borgeson, T.L.; Thiessen, D.L. A review of processing of feed ingredients to enhance diet digestibility in finfish. Anim. Feed Sci. Technol. 2007, 138, 118-136. [CrossRef]

13. Khadijat, B.M.; Enoch, O.O.; Suleiman, B.E. Performance, carcass characteristics and blood composition of broilers fed varying levels of palm kernel meal (Elaise guinensis) supplemented with different levels of fish meal. Int. J. Poult. Sci. 2012, 11, 73-77. [CrossRef]

14. Saenphoom, P.; Liang, J.B.; Ho, Y.W.; Loh, T.C.; Rosfarizan, M. Effects of enzyme treated palm kernel expeller on metabolizable energy, growth performance, villus height and digesta viscosity in broiler chickens. Asian Aust. J. Anim. Sci. 2013, 26, 537-544. [CrossRef] [PubMed]

15. Ng, W.K.; Lim, H.A.; Lim, S.L.; Ibrahim, C.O. Nutritive value of palm kernel meal pretreated with enzymes or fermented with Trichoderma koningii (Oudemans) as a dietary ingredient for red hybrid tilapia (Oreochromis sp.). Aquac. Res. 2002, 33, $1199-1207$. [CrossRef]

16. Ng, W.K.; Chen, M.L. Replacement of soybean meal with palm kernel meal in practical diets for hybrid Asian-African catfish, Clarias macrocephalus $\times$ C. gariepinus. J. Appl. Aquac. 2002, 12, 67-76. [CrossRef]

17. Thongprajukaew, K.; Rodjaroenc, S.; Tantikitti, C.; Kovitvadhi, U. Physicochemical modifications of dietary palm kernel meal affect growth and feed utilization of Nile tilapia (Oreochromis niloticus). Anim. Feed Sci. Technol. 2015, 202, 90-99. [CrossRef]

18. Thongprajukaew, K.; Rodjaroenc, S.; Yoonram, K.; Sornthong, P.; Hutcha, N.; Tantikitti, C.; Kovitvadhi, U. Effects of dietary modified palm kernel meal on growth, feed utilization, radical scavenging activity, carcass composition and muscle quality in sex reversed Nile tilapia (Oreochromis niloticus). Aquaculture 2015, 439, 45-52. [CrossRef]

19. Esatu, W.; Melesse, A.; Dessie, T. Effect of effective microorganisms on growth parameters and serum cholesterol levels in broilers. Afr. J. Agric. Res. 2011, 6, 3841-3846.

20. AOAC. Official Methods of Analysis of AOAC International, 15th ed.; Association of Official Analytical Chemists: Arlington, VA, USA, 1990; pp. 69-90.

21. Lowry, O.H.; Rosenbrough, N.J.; Farr, A.L.; Randall, R.J. Protein measurement with the Folin phenol reagent. J. Biol. Chem. 1951, 193, 265-275. [CrossRef]

22. Worthington, V. Worthington Enzyme Manual. Enzymes and Related Biochemicals; Worthington Chemical: Lakewood, NJ, USA, 1993; p. 399.

23. Rungruangsak-Torrissen, K.; Moss, R.; Andresen, L.H.; Berg, A.; Waagbo, R. Different expressions of trypsin and chymotrypsin in relation to growth in Atlantic salmon (Salmo salar L.). Fish Physiol. Biochem. 2006, 32, 7-23. [CrossRef]

24. Areekijseree, M.; Engkagul, A.; Kovitvadhi, U.; Thongpan, A.; Mingmuang, M.; Pakkong, P.; Rungruangsak-Torrissen, K. Temperature and $\mathrm{pH}$ characteristics of amylase and proteinase of adult freshwater pearl mussel, Hyriopsis (Hyriopsis) bialatus Simpson 1900. Aquaculture 2004, 234, 575-587. [CrossRef]

25. Mendels, M.; Weber, J. The product of cellulose in cellulase and their application. Adv. Chem. Ser. 1969, 95, 390-443.

26. Winkler, U.K.; Stuckmann, M. Glycogen, hyaluronate and some other polysaccharides greatly enhance the formation of exolipase by Serratia marcescens. J. Bacteriol. 1979, 138, 663-670. [CrossRef]

27. Nonthaput, T.; Hahor, W.; Thongprajukaew, K.; Yoonram, K.; Rodjaroen, S. Cathepsin activities and thermal properties of Nile tilapia (Oreochromis niloticus) meat during ambient storage. Agric. Nat. Res. 2017, 51, 206-211. [CrossRef]

28. Blaxhall, P.C.; Daisley, K.W. Routine haematological methods for use with fish blood. J. Fish Biol. 1973, 5, 771-781. [CrossRef]

29. Larsen, H.N.; Snieszko, S.F. Comparison of various methods of determination of haemoglobin in trout blood. Prog. Fish-Cult. 1961, 23, 8-17. [CrossRef]

30. Larsen, H.N.; Snieszko, S.F. Modification of the microhematocrit technique with trout blood. Trans. Amer. Fish. Soc. 1961, 90, 139-142. [CrossRef]

31. Javed, M.; Ahmad, I.; Ahmad, A.; Usmani, N.; Ahmad, M. Studies on the alterations in haematological indices, micronuclei induction and pathological marker enzyme activities in Channa punctatus (spotted snakehead) Perciformes, Channidae exposed to thermal power plant effluent. SpringerPlus 2016, 5, 1-9. [CrossRef] [PubMed]

32. Suvarna, K.S.; Layton, C.; Bancroft, J.D. Bancroft's Theory and Practice of Histological Techniques, 7th ed.; Elsevier: North York, ON, Canada, 2013; pp. 40-95.

33. Dairo, F.A.S.; Fasuyi, A.O. Evaluation of fermented palm kernel meal and fermented copra meal proteins as substitute for soybean meal protein in laying hens diets. J. Cent. Eur. Agric. 2008, 9, 35-44.

34. Alshelmani, M.I.; Loh, T.C.; Foo, H.L.; Sazili, A.Q.; Lau, W.H. Effect of solid state fermentation on nutrient content and ileal amino acids digestibility of palm kernel cake in broiler chickens. Ind. J. Anim. Sci. 2017, 87, 1135-1140.

35. Dusterhoft, E.M.; Voragen, A.G.J. Nonstarch polysaccharides from sunflower (Helianthus annuus) and palm kernel (Elaeis.guineensis) meal: Preparation of cell wall material and extraction of polysaccharide fractions. J. Sci. Food Agric. 1991, 55, 411-422. [CrossRef]

36. Halliwell, G.; Wahab, M.N.B.A.; Patel, A.H. The contribution of endo-1,4- $\beta$-D-glucanase to cellulolysis in Trichoderma koningii. J. Appl. Biochem. 1985, 7, 43-54. 
37. Ahmed, S.T.; Mun, H.-S.; Islam, M.M.; Ko, S.-Y.; Yang, C.-J. Effects of dietary natural and fermented herb combination on growth performance, carcass traits and meat quality in grower-finisher pigs. Meat Sci. 2016, 122, 7-15. [CrossRef]

38. Oso, A.O.; Li, L.; Zhang, B.; Uo, R.; Fan, J.X.; Wang, S.; Jiang, G.; Liu, H.; Rahoo, T.; Tossou, M.C.; et al. Effect of fungal fermentation with Aspergillus niger and enzyme supplementation on metabolizable energy values of unpeeled cassava root meal for meat-type cockerels. Anim. Feed Sci. Technol. 2015, 210, 281-286. [CrossRef]

39. Deng, J.; Mai, K.; Chen, L.; Mi, H.; Zhang, L. Effects of replacing soybean meal with rubber seed meal on growth, antioxidant capacity, non-specific immune response, and resistance to Aeromonas hydrophila in tilapia (Oreochromis niloticus $\times$ O. aureus). Fish Shell. Immunol. 2015, 44, 436-444. [CrossRef] [PubMed]

40. Azaza, M.S.; Wassim, K.; Mensi, F.; Abdelmouleh, A.; Brini, B.; Kraïem, M.M. Evaluation of faba beans (Vicia faba L. var. minuta) as a replacement for soybean meal in practical diets of juvenile Nile tilapia Oreochromis niloticus. Aquaculture 2009, 287, 174-179. [CrossRef]

41. Barros, M.M.; Lim, C.; Klesius, P.H. Effect of soybean meal replacement by cottonseed meal and iron supplementation on growth, immune response and resistance of channel catfish (Ictalurus puctatus) to Edwardsiella ictaluri challenge. Aquaculture 2002, 207, 263-279. [CrossRef]

42. Choct, M.; Annison, G. Anti-nutritive effect of wheat pentosans in broiler chickens: Roles of viscosity and gut microflora. Br. Poult. Sci. 1992, 33, 821-834. [CrossRef] [PubMed]

43. Thongprajukaew, K.; Rodjaroen, S. Intermittent feeding induces compensatory growth of juvenile yellow mystus (Hemibagrus nemurus). Aquat. Liv. Res. 2017, 30, 6. [CrossRef]

44. Eshel, A.; Lindner, P.; Smirnoff, P.; Newton, S.; Harpaz, S. Comparative study of proteolytic enzymes in the digestive tracts of the European sea bass and hybrid striped bass reared in freshwater. Comp. Biochem. Physiol. 1993, 106A, 627-634. [CrossRef]

45. Romijn, J.A.; Godfried, M.H.; Hommes, M.J.T.; Endert, E.; Sauerwein, H.P. Decreased glucose oxidation during short-term starvation. Metabolism 1990, 39, 525-530. [CrossRef]

46. Carter, C.G.; He, Z.Y.; Houlihan, D.F.; McCarthy, I.D.; Davidson, I. Effects of feeding on the tissue free amino acid concentrations in rainbow trout (Oncorhynchus mykiss Walbaum). Fish Physiol. Biochem. 1995, 14, 153-164. [CrossRef] [PubMed]

47. Thongprajukaew, K.; Kovitvadhi, U.; Kovitvadhi, S.; Engkagul, A.; Rungruangsak-Torrissen, K. Evaluation of growth performance and nutritional quality of diets using enzymatic markers and in vitro digestibility in Siamese fighting fish (Betta splendens Regan, 1910). Afr. J. Biotechnol. 2013, 12, 1689-1702.

48. Matos, E.; Silva, T.S.; Tiago, T.; Aureliano, M.; Dinis, M.T.; Dias, J. Effect of harvesting stress and storage conditions on protein degradation in fillets of farmed gilthead seabream (Sparus aurata): A differential scanning calorimetry study. Food Chem. 2011, 126, 270-276. [CrossRef]

49. Das, B.K.; Mukherjee, S.C. Toxicity of cypermethrin in Labeo rohita fingerlings: Biochemical enzymatic and haematological consequence. Comp. Biochem. Physiol. 2003, 134C, 109-121. [CrossRef]

50. Sharma, B.B.; Saha, R.K.; Saha, H. Effects of feeding detoxified rubber seed meal on growth performance and haematological indices of Labeo rohita (Hamilton) fingerlings. Anim. Feed Sci. Technol. 2014, 193, 84-92. [CrossRef]

51. Hong, K.J.; Lee, C.H.; Kim, S.W. Aspergillus oryzae 3.042GB-107 fermentation improves nutritional quality of food soybeans and feed soybean meals. J. Med. Food. 2004, 7, 430-434. [CrossRef]

52. Sitjà-Bobadilla, A.; Peña-Llopis, S.; Gómez-Requeni, P.; Médale, F.; Kaushik, S.; Pérez-Sánchez, J. Effect of fish meal replacement by plant protein sources on non-specific defence mechanisms and oxidative stress in gilthead sea bream (Sparus aurata). Aquaculture 2005, 249, 387-400. [CrossRef] 